PERM JOURNAL OF PETROLEUM AND MINING ENGINEERING

ВЕСТНИК ПНИПУ. ГЕОЛОГИЯ. НЕФТЕГАЗОВОЕ И ГОРНОЕ ДЕЛО

ISSN 2224-9923

Volume / Tом 20 №2, 2020

http://vestnik.pstu.ru/gee

UDC 622.276+553.982.23.08(470.13)

Article / Статья

(C) PNRPU / ПНИПУ, 2020

\title{
THE INFLUENCE OF ROCK LITHOGENESIS TYPES \\ ON POROSITY AND PERMEABILITY (THE CASE OF PERMO- CARBONIFEROUS DEPOSIT OF THE USINSKOYE FIELD)
}

\author{
Nikita A. Popov, Ivan S. Putilov, Anastasiia A. Guliaeva, Ekaterina E. Vinokurova, luliia V. Fairuzova
}

PermNIPIneft branch of LUKOIL-Engineering LLC in Perm (3a Permskaya st., Perm, 614015, Russian Federation)

\section{ВЛИЯНИЕ ЛИТОГЕНЕТИЧЕСКОГО ТИПА ГОРНЫХ ПОРОД НА ФИЛЬТРАЦИОННО-ЕМКОСТНЫЕ СВОЙСТВА (НА ПРИМЕРЕ ПЕРМОКАБОНОВОЙ ЗАЛЕЖИ УСИНСКОГО МЕСТОРОЖДЕНИЯ)}

\section{Н.А. Попов, И.С. Путилов, А.А. Гуляева, Е.Е. Винокурова, Ю.В. Файрузова}

Филиал ООО «ЛУКОЙЛ-Инжиниринг» «ПермНИПИнефть» в г. Перми (614015, Россия, г. Пермь, ул. Пермская, 3a)

Received / Получена: 07.02.2020. Accepted / Принята: 15.04.2020. Published / Опубликована: 15.06.2020

\section{Key words:}

laboratory core studies, porosity and permeability properties anisotropy of properties, full-size core samples, mathematical and statistical analysis, the Dunham classification.

\begin{abstract}
The paper analyzes a methodology aimed at differentiation of porosity, permeability and petrographic properties depending on facies attributes. Based on the Dunham classification, we offer in-depth studies of the influence of rock fabric, including full-size core samples, on changes in porosity and permeability. The work deals with the Permo-Carboniferous deposit of the Usinskoye field. Reservoir properties of the considered strata are highly heterogeneous. Along with highly porous and cavernous rocks, there are low porous and fractured varieties in the section, which refer to rocks of various lithological compositions.

The porosity and permeability properties were analysed for more than 9,000 standard core samples and approximately The porosity and permeability properties we an ty 1,000 full-size core samples, taking into account the scale factor and including matrix, commensurable with the sample sizes. The analysis of the maximum variation range is of particular importance for structurally complex carbonate reservoirs. Furthermore, based on the conducted lithologic, petrographic and petrophysical studies, the authors identified four types of reservoirs and eight different types of lithogenesis, as well as estimated geological and physical parameters for each of them. Based on the cumulative correlation plots, four zones of heterogeneity were identified. They are subject to the influence of properties of the core samples of different lithogenesis types. This is the first time that the influence of various petrotypes/lithotypes on changes in the reservoir porosity and permeability has been studied for the Usinskoye field based on the petrographic and petrophysical research findings. All the conducted experiments show that the rocks of the Permo-Carboniferous deposit of the Usinskoye field are extremely heterogeneous in their permeability properties that vary much. Thus, it is necessary to differentiate the core-to-core petrophysical correlations depending on a void space fabric and lithology of rocks.
\end{abstract}

Анализируется разработка методических приемов для лифференшиании фильтрачионно-емкостных и петрографических свойств в зависимости от фациальной принадлежности. Детально изучено влияние структуры по Данему на изменения фильтрационно-емкостных свойств, в том числе с использованием полноразмерных образцов керна. В качестве объекта исследований выбрана пермокарбоновая залежь Усинского месторождения. Коллекторские характеристики рассматриваемой толщи весьма неоднородны: наряду с высокопористыми и кавернозными породами в разрезе имеются низкопористые и трещиноватые разности, причем это относится к породам разного литологического состава.

Изучение фильтрационно-емкостных свойств было проведено более чем на 9000 стандартных образцов керна и около 1000 образцов полноразмерного керна, которые учитывают масштабный фактор и включают в себя микротрещины, каверны большого размера и матрицу породы, соизмеримые с размерами образцов. Для сложнопостроенных карбонатных коллекторов особенно важным является анализ максимального диапазона изменений. В свою очередь на основании проведенных литолого-петрографических и петрофизических исследований авторами было выделено четыре типа коллекторов и восемь различных литогенетических типов, для каждого из которых оценены геолого-физические параметры. На основании построенных графиков накопленной корреляции удалось выделить четыре зоны неоднородности, которые обусловлены влиянием свойств образцов керна разных литогенетических типов. По результатам проведенных петрографических и петрофизических исследований впервые для Усинского месторождения изучено проведенных петрография влияние различных петролитотипов на изменения фильтрационно-емкостных свойств коллекторов. С учетом всех проведенных экспериментов установлено, что породы пермокарбоновой залежи Усинского месторождения характеризуются крайней неоднородностью емкостных свойств, меняющихся в широких пределах. В связи с этим необходимо выполнять дифференциации петрофизических связей типа «керн - керн» в зависимости от структуры

Nikita A. Popov (Scopus ID 56088494600) - Head of the Department for Comprehensive Core Research of the Center for Core and Formation Fluid Research (tel.: + 007342701 57, e-mail: Nikita.Popov@pnn.lukoil.com). The contact person for correspondence.

Ivan S. Putilov (S7, e-mail. Nikita.Popov@pnn.lukoil.com). The contact person for correspondence. e-mail: Ivan.Putilov@pnn.lukoil.com).

Anastasiia A. Guliaeva $-2^{\text {nd }}$ category Engineer of the Division for Estimation of the Reserves of the Northern group fields of the Volga-Ural region (tel.: +00734236491 , e-mail: Anastasija.Guljaeva@pnn.lukoil.com).

Ekaterina E. Vinokurova - Chief Specialist of the Division of Lithology and Stratigraphy of the Department for Comprehensive Core Research of the Center for Core and Formation fluid Research (tel.: +007 342364 99, e-mail: Ekaterina.Vinokurova@pnn.lukoil.com).

Iuliia V. Fairuzova -2 $2^{\text {nd }}$ category Geologist of the Division of Geological Modeling of the Timan-Pechora region (tel.: +007 342 364 91, e-mail: Yulija.Fairuzova@pnn.lukoil.com).

Попов Никита Андреевич - начальник Управления комплексных исследований керна Центра исследования керна и пластовых флюидов (тел.: + 00734270157 , e-mail: Nikita.Popov@pnn.lukoil.com). Контактное лицо для переписки.

Путилов Иван Сергеевич - доктор технических наук, заместитель директора филиала по научной работе в области геологии (тел.: +007 34236458 , e-mail: Ivan.Putilov@pnn.lukoil.com).

Гуляева Анастасия Андревна

(1) 2-й категории

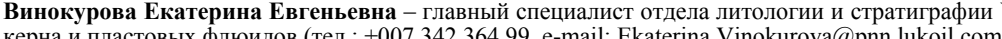

жал и пластовых флюидов (тел.. +007342364 99, e-mail: Ekaterina.Vinokurova@pnn.lukoil.com). Ф-mail: Yulija.Fairuzova@pnn.lukoil.com). 


\section{Introduction}

Porosity and permeability data are essential when preparing an engineering design package, calculating oil and gas reserves, performing geological modelling and planning exploration activities. Based on the Dunham classification, this work offers an indepth study of how a structure may change porosity and permeability of rock fabrics, including full-size core samples.

A new methodology is developed to differentiate porosity, permeability and petrographic properties depending on facies attributes. A correct estimation of porosity and permeability of reservoirs under development largely depends on sufficiency of the petrophysical basis [1-3]. Only laboratory studies of core samples can serve as a direct way of obtaining such information [4-9].

\section{Laboratory Studies}

The paper aims at studying the PermoCarboniferous deposit of the Usinskoye field. The porosity and permeability properties were analysed for more than 9,000 standard core samples and approximately 1,000 full-size core samples, taking into account the scale factor and including microfractures, large caverns and rock matrix, commensurable with the sample sizes [10-16]. The coverage of the maximum variation range of porosity and permeability is of particular importance for structurally complex carbonate reservoirs [17]. The open porosity ratio for the standard core samples was determined by the fluid saturation method (the Preobrazhensky method) and hydrostatic weighing taking external caverns into account, according to the National Standard GOST 26450.1-85 [18]. While the open porosity ratio for the full-size samples was determined using the MR-ISM-03-OLFI-046-2013 method [19]. As a result of the lithologic, petrographic and petrophysical studies, it is revealed that the rocks of the studied section have heterogeneous but quite good porosity and permeability properties. This fact is associated with the facies attribute, i.e. the distribution of pores, caverns and fractures, as well as their morphological features. The lithological and petrographic data show that the studied rocks (in this section) have undergone a wide range of postdepositional alterations in their geological evolution, e.g. compaction, recrystallization, calcitization, dolomitization, silicification, stylolization, fracturing and leaching. Each of these secondary processes had an unclear effect on the void space formation at various lithogenesis stages. Therefore, their intensity varies in carbonate rocks of different textures.

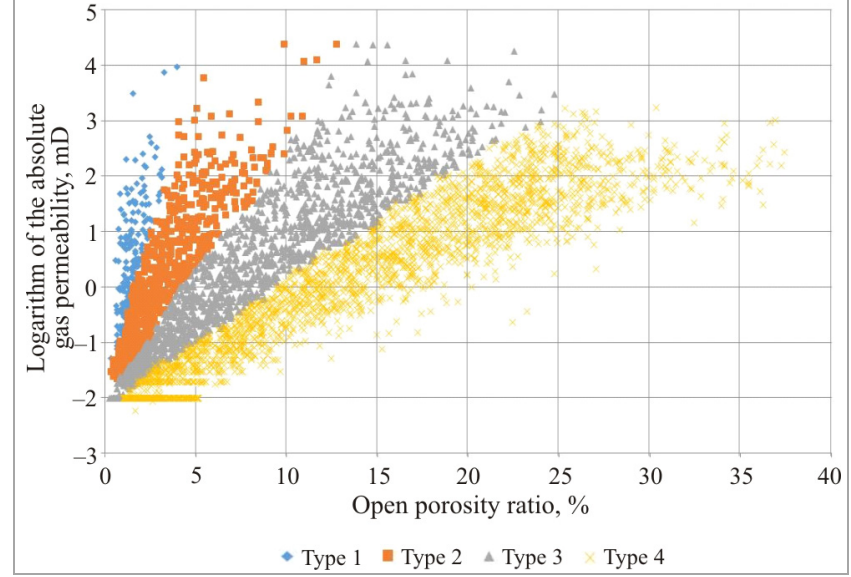

Fig. 1. Comparison of the open porosity and gas permeability of the standard samples of carbonate rocks of the Permo-Carboniferous deposit

The porosity and permeability properties of the strata are quite heterogeneous. Along with highly porous and cavernous rocks, there are low-porous and fractured varieties in the section, which refers to rocks of different lithological compositions. For such reservoirs, it is of prime importance to conduct studies on both standard and full-diameter core samples, as the latter accurately reflect the flow pattern of the processes occurring in the reservoir. [20-38]. There are intervals with sediments having both low matrix porosity and high permeability. Studying the void space of the rocks in this section allowed us to identify its texture and fabric, as well as to determine reservoir types by using the petrophysical analyses results. In general, the sediments of this section can be attributed to a composite reservoir with various flow properties. A collection of 5,000 core samples of a regular geometric shape was selected from all the samples for special lithologic, petrographic and petrophysical studies. They were used to determine the open porosity and absolute gas permeability. The studies made it possible to identify four types of reservoirs with different pore structures (Fig. 1).

1. Fractured reservoir (fractures are present): fractures are central to porosity and permeability.

2. Fractured cavernous porous reservoir (caverns and fractures are present): a composite type of reservoir, all types of voids affect porosity and permeability.

3. Cavernous porous reservoir: this group includes samples with a large cavern volume.

4. Porous reservoir (no caverns and/or fractures): pore channels are central to porosity and permeability.

Reservoirs of the first type exhibit low matrix porosity. The increased gas permeability ratio results from horizontal and inclined arrangements of fractures. The fractures are open, intermittent, short and extensive; they are limited to areas enriched in clay matter and stylolite. The secondary leached pores are formed along the fractures. It is noted that there are singular mineral fractures with a tortuous geometry, 
they are intermittent and formed by the pale fine shortgrained calcite or silica in individual cases.

For reservoirs of the second type, the role of fractures as additional flow paths of the bituminous organic matter is of great importance. The rock permeability is determined by secondary and primary pores. The primary pores feature sedimentation and diagenetic recrystallization pores, while the secondary pores feature leached pores, those inherited from the primary pores and those newly formed along the fractures and stylolites. The fractures are not consistent in width; they are extensive and short, tortuous and rectilinear. The fractures are leached in sections. There are multiple filamentary closed fractures.

Reservoirs of the third type feature changes in the porosity and permeability over a wide range. The pores and leached caverns are irregular, elongated and isometric in shape. The pores are interconnected. Some of the fine intergranular pores (dolomization/ recrystallization pores) are partially or completely filled with the brown bituminous organic matter. Some voids are formed due to leaching of organic remains (dissolution porosity). Locally, the pores are filled with authigenic siliceous material represented by quartz and flabellate chalcedony, which is less common. Compared to Type 2, stylolite occurred less often in Type 3.

Type 4 refers to the porous type of reservoir. The voids are created nonuniformly, mainly in cement, and they are less often in intramatrix cavities of organic residues. The cavities are highly diverse in shape. Individual cavities are partially or completely healed with calcite. Fine pores are sometimes filled with the brown bituminous organic matter. Some pores take the shape of organic remains (moldic porosity). Interparticle and moldic pores sometimes develop near stylolite seams, as well as in stylolite separation films and along mineral and open fractures.

Table 1 shows the distribution of the open porosity ratio and absolute gas permeability depending on the reservoir types. Based on the obtained statistical results, we can conclude that 173 core samples $(3.2 \%)$ pertain to the cavernous reservoir; 797 samples (14.7\%) pertain to the fractured cavernous porous reservoir; 1,675 samples $(30.9 \%)$ pertain to the cavernous porous reservoir; and 2,782 (51.2\%) pertain to the porous reservoir. Thus, most considered samples belong to the porous type of reservoir, while the least number of the samples belong to the fractured type. The fractured reservoir porosity is up to $2 \%$, while the permeability reaches the values of up to $10 \mathrm{D}$ (darcy units). The open porosity of the fractured cavernous porous reservoir varies within the range from 0 to $17 \%$, and the gas permeability exceeds $1 \mathrm{D}$. For the cavernous porous reservoir, the open porosity lies in the range from 0 to $27 \%$, while the gas permeability is over $1 \mathrm{D}$. For the porous reservoir, the open porosity ranges from 0 to $37 \%$, and the gas permeability is up to $1 \mathrm{D}$.

Table 1

Distribution of the ratio of open porosity and absolute gas permeability depending on reservoir types

\begin{tabular}{|c|c|c|c|c|c|c|c|c|c|}
\hline \multirow{3}{*}{ Parameter } & \multicolumn{8}{|c|}{ Reservoir type } & \multirow{3}{*}{$\begin{array}{c}\text { Total number, } \\
\text { pcs. }\end{array}$} \\
\hline & \multicolumn{2}{|c|}{ Fractured reservoir } & \multicolumn{2}{|c|}{$\begin{array}{l}\text { Fractured cavernous } \\
\text { porous reservoir }\end{array}$} & \multicolumn{2}{|c|}{$\begin{array}{l}\text { Cavernous porous } \\
\text { reservoir }\end{array}$} & \multicolumn{2}{|c|}{ Porous reservoir } & \\
\hline & abs. & $\%$ & abs. & $\%$ & abs. & $\%$ & abs. & $\%$ & \\
\hline \multicolumn{10}{|l|}{ Kpor, \%: } \\
\hline $\begin{array}{l}\text { From } 0 \text { to } 5 \\
(\text { Zone } 1)\end{array}$ & 173 & 7.2 & 665 & 27.5 & 714 & 29.5 & 866 & 35.8 & 2418 \\
\hline \begin{tabular}{|l|} 
From 5 to 12 \\
(Zone 2$)$
\end{tabular} & 0 & 0.0 & 131 & 10.3 & 595 & 46.6 & 551 & 43.1 & 1277 \\
\hline $\begin{array}{l}\text { From } 12 \text { to } 20 \\
\text { (Zone 3) }\end{array}$ & 0 & 0.0 & 1 & 0.1 & 339 & 33.9 & 661 & 66.0 & 1001 \\
\hline \begin{tabular}{|l|} 
Over 20 \\
(Zone 4)
\end{tabular} & 0 & 0.0 & 0 & 0.0 & 27 & 3.7 & 704 & 96.3 & 731 \\
\hline \begin{tabular}{|l|} 
Average value \\
for all zones \\
\end{tabular} & 173 & 3.2 & 797 & 14.7 & 1675 & 30.9 & 2782 & 51.2 & 5427 \\
\hline \multicolumn{10}{|l|}{ Kperm, mD: } \\
\hline \begin{tabular}{|l|}
$0.01-1$ \\
(Zone 1) \\
\end{tabular} & 56 & 2.0 & 450 & 16.1 & 835 & 29.9 & 1448 & 51.9 & 2789 \\
\hline $\begin{array}{l}\text { From } 1 \text { to } 10 \\
(\text { Zone } 2)\end{array}$ & 64 & 6.1 & 161 & 15.4 & 305 & 29.2 & 513 & 49.2 & 1043 \\
\hline \begin{tabular}{|l|}
$\begin{array}{l}\text { From } 10 \text { to } 100 \\
\text { (Zone } 3 \text { ) }\end{array}$ \\
\end{tabular} & 39 & 3.8 & 126 & 12.4 & 296 & 29.2 & 552 & 54.5 & 1013 \\
\hline \begin{tabular}{|l|} 
Over 100 \\
(Zone 4)
\end{tabular} & 14 & 2.4 & 60 & 10.3 & 239 & 41.1 & 269 & 46.2 & 582 \\
\hline $\begin{array}{l}\text { Average value } \\
\text { for all zones } \\
\end{array}$ & 173 & 3.2 & 797 & 14.7 & 1675 & 30.9 & 2782 & 51.2 & 5427 \\
\hline
\end{tabular}




\section{Analysis of the Obtained Results}

Based on the conducted lithological and petrographic studies, we identified the lithogenesis types in the rocks of the Usinskoye field, such as Mudstone, Wackestone, Packstone, Grainstone, Boundstone, Floatstone, Rudstone and Crystalline Carbonate. Table 2 shows the comparison of the texture types (according to the Dunham classification) with their geological and physical parameters. The analysis of average dispersion values and parameter intervals shows that it is impossible to dividing the texture types into geological and geophysical parameters [39-46]. Among all the studied lithogenesis types, Crystalline Carbonate exhibits the best porosity and permeability properties: the average open porosity is $19.51 \%$, and the average absolute gas permeability is $106.71 \mathrm{mD}$. Floatstone exhibits the lowest porosity and permeability properties: the average open porosity is $7.65 \%$, while the average absolute gas permeability is $6.41 \mathrm{mD}$.

A graph of Pearson's cumulative correlation against the open porosity ratio was plotted to offer an in-depth study of how the lithological features affect changes in permeability for 5,000 core samples (Fig. 2, a). The discontinuities, interruptions and curvature in the graph reflect changes in the structure of the pore space in different ranges and allow the inhomogeneity areas to be identified. There are four zones, which can be singled out in the graph, depending on the properties of the core samples that belong to different lithogenesis types.

To assess the impact of the different lithogenesis properties on permeability of the samples, we plotted a similar graph of Pearson's cumulative correlation against the open porosity ratio by using more than 1,000 samples, for which it was possible to identify their attribution to a particular texture as per the Dunham classification (Fig. 2, b). Similarly to Fig. 2, $a$, four zones can be observed in the graph. Despite the smaller sample array, the nature of the graph is generally identical to that shown in Fig. 2, $a$. As it can be seen in Fig. $2(a, b)$, in the open porosity range of 0 to $5 \%$ in Zone 1 , there is a scatter of points across the core samples. In the porosity range of 5 to $20 \%$, the correlation shows a smooth growth with some correlation discontinuities, which are due to the change in the void space structure and the influence of the rocks of various lithogenesis types. There starts a close-to-complete stabilisation with the porosity of $20 \%$ (Zone 4), since only one lithogenesis type Crystalline Carbonate - contributes to the void space of the rocks. Table 3 shows the contribution of the Dunham texture to the open porosity distribution over the entire property range for each zone. For the open porosity in the range from 0 to $20 \%$, the Boundstone contributes the most, while Crystalline Carbonate makes up more than $20 \%$. Mudstone, Wackestone and Floatstone have the least impacts.

Table 2

Correlation between the Dunham rock classification and Laboratory geological and physical parameters of rocks

\begin{tabular}{|c|c|c|c|c|c|c|c|}
\hline \multirow{2}{*}{$\begin{array}{l}\text { Texture type } \\
\text { as per Dunham }\end{array}$} & \multicolumn{7}{|c|}{ Geological and physical parameters } \\
\hline & $\begin{array}{c}\text { Number } \\
\text { of definitions }\end{array}$ & $\begin{array}{c}\text { Permeability, } \\
10^{-3} \mu \mathrm{m}^{2}\end{array}$ & $\begin{array}{c}\text { Porosity, } \\
\%\end{array}$ & $\begin{array}{l}\text { Density min., } \\
\mathrm{g} / \mathrm{cm}^{3}\end{array}$ & $\begin{array}{c}\text { Calcite } \\
\text { content, \% }\end{array}$ & $\begin{array}{l}\text { Dolomite } \\
\text { content, \% }\end{array}$ & $\begin{array}{c}\text { Insoluble } \\
\text { constituent, \% }\end{array}$ \\
\hline Mudstone & 6 & $\frac{152.42 \pm 129.17}{3.27-227.00}$ & $\frac{10.14 \pm 7.18}{1.85-14.28}$ & $\frac{2.68 \pm 0.01}{2.68-2.69}$ & $\frac{35.90 \pm 28.20}{19.60-68.50}$ & $\frac{3.00 \pm 5.25}{0.00-9.10}$ & $\frac{61.00 \pm 33.46}{22.40-80.40}$ \\
\hline Wackestone & 14 & $\frac{8.08 \pm 12.30}{0.01-26.01}$ & $\frac{5.35 \pm 0.93}{3.99-6.00}$ & $\frac{2.70 \pm 0.02}{2.67-2.72}$ & $\frac{93.10 \pm 10.60}{77.40-100.00}$ & $\frac{0.70 \pm 1.45}{0.00-2.90}$ & $\frac{6.20 \pm 10.95}{0.00-22.60}$ \\
\hline Packstone & 225 & $\frac{9.13 \pm 33.47}{0.01-257.20}$ & $\frac{6.62 \pm 5.84}{0.59-27.02}$ & $\frac{2.70 \pm 0.02}{2.64-2.83}$ & $\frac{86.50 \pm 22.16}{0.00-100.00}$ & $\frac{5.20 \pm 16.52}{0.00-98.00}$ & $\frac{8.30 \pm 15.90}{0.00-74.80}$ \\
\hline Grainstone & 190 & $\frac{13.16 \pm 35.41}{0.01-242.60}$ & $\frac{9.33 \pm 6.32}{0.51-22.45}$ & $\frac{2.70 \pm 0.01}{2.66-2.74}$ & $\frac{95.60 \pm 7.10}{52.70-100.00}$ & $\frac{0.10 \pm 0.61}{0.00-6.80}$ & $\frac{4.40 \pm 7.05}{0.00-47.30}$ \\
\hline Boundstone & 427 & $\frac{97.85 \pm 325.33}{0.01-2016.00}$ & $\frac{6.90 \pm 5.98}{0.37-25.58}$ & $\frac{2.70 \pm 0.02}{2.64-2.84}$ & $\frac{93.50 \pm 11.36}{0.00-100.00}$ & $\frac{1.10 \pm 7.68}{0.00-100.00}$ & $\frac{5.40 \pm 8.07}{0.00-70.20}$ \\
\hline Floatstone & 43 & $\frac{6.41 \pm 13.95}{0.01-46.97}$ & $\begin{array}{l}.65 \pm 6.64 \\
0.73-21.91 \\
\end{array}$ & $\frac{2.72 \pm 0.05}{2.68-2.88}$ & $\frac{88.20 \pm 22.81}{0.00-100.00}$ & $\frac{7.30 \pm 21.04}{0.00-86.80}$ & $\begin{array}{l}4.50 \pm 3.80 \\
0.00-13.20\end{array}$ \\
\hline Rudstone & 197 & $\frac{10.87 \pm 46.56}{0.01-300.50}$ & $\frac{4.50 \pm 4.00}{0.98-21.89}$ & $\frac{2.69 \pm 0.02}{2.62-2.78}$ & $\frac{94.10 \pm 8.63}{52.90-100.00}$ & $\frac{3.00 \pm 7.69}{0.00-47.10}$ & $\frac{2.90 \pm 3.57}{0.00-22.20}$ \\
\hline $\begin{array}{l}\text { Crystalline } \\
\text { Carbonate } \\
\text { (dolomite) }\end{array}$ & 148 & $\frac{106.71 \pm 200.27}{0.01-1055.00}$ & $\frac{19.51 \pm 9.73}{0.94-37.02}$ & $\frac{2.80 \pm 0.04}{2.69-2.84}$ & $\frac{18.40 \pm 32.87}{0.00-99.00}$ & $\frac{74.70 \pm 32.02}{0.00-98.60}$ & $\frac{7.00 \pm 6.98}{0.00-33.60}$ \\
\hline
\end{tabular}

N o t e : the gas permeability ratio $(\mathrm{mD})$ is in the numerator; the zone number is in the denominator. 

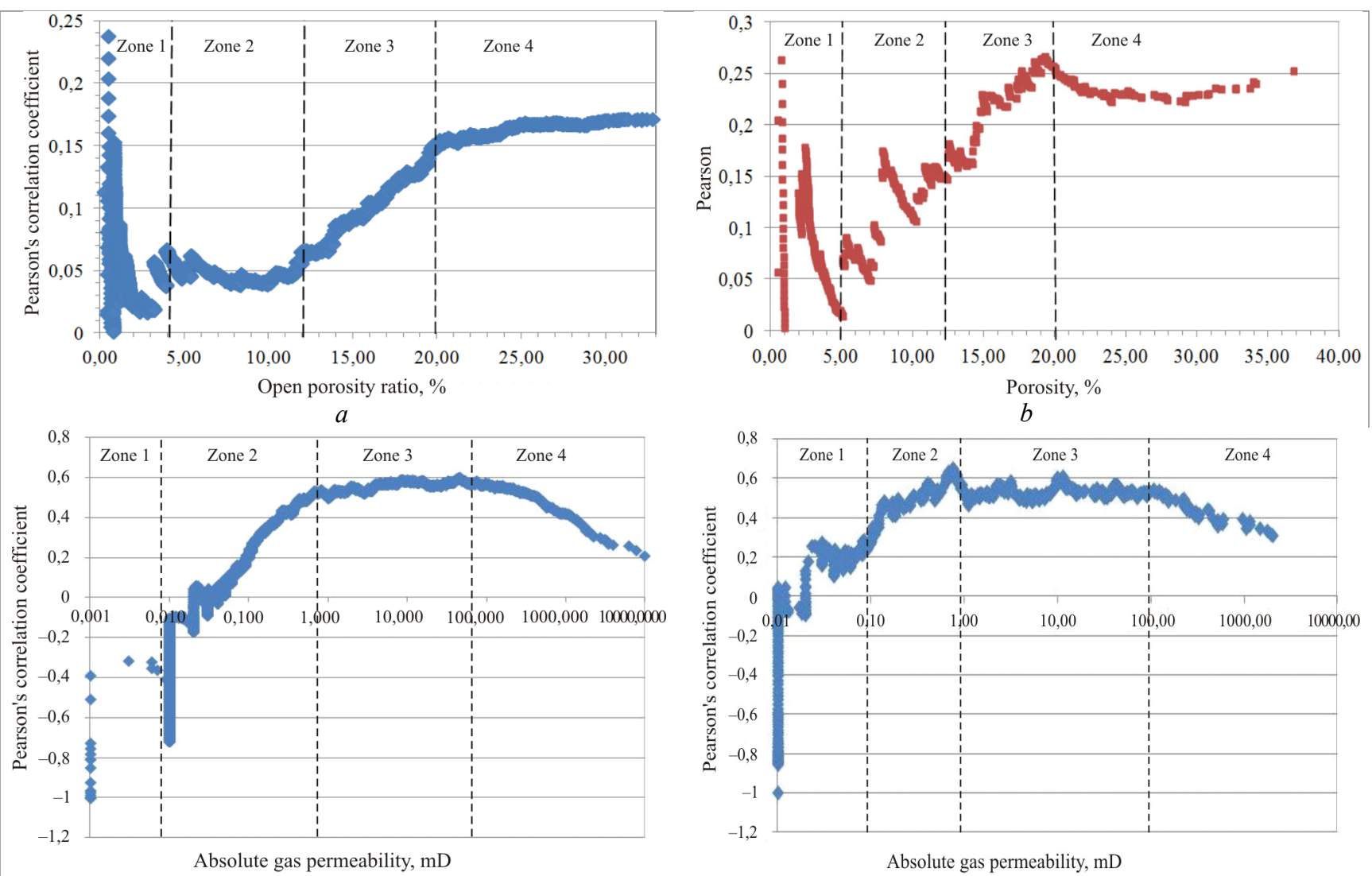

$c$

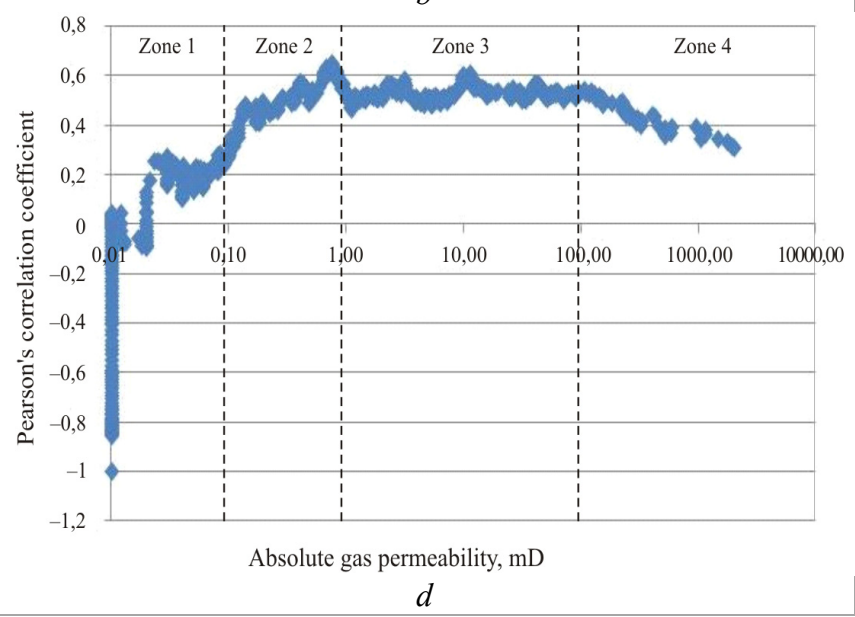

Fig. 2. Graph of Pearson's correlation coefficient change: $a$ - against the open porosity for all the samples; $b$-against the open porosity for the samples with the identified Dunham texture; $c$ - against the absolute gas permeability for all the samples; $d$-against the absolute gas permeability for the samples with the identified Dunham texture. The graphs show standard-size samples

Table 3

Contribution of the Dunham texture to the distribution of the open porosity and gas permeability over the entire range of properties

\begin{tabular}{|c|c|c|c|c|c|c|c|c|c|c|c|c|c|c|c|c|c|}
\hline \multirow{2}{*}{ Parameter } & \multicolumn{2}{|c|}{ Mudstone } & \multicolumn{2}{|c|}{ Wackestone } & \multicolumn{2}{|c|}{ Packstone } & \multicolumn{2}{|c|}{ Grainstone } & \multicolumn{2}{|c|}{ Boundstone } & \multicolumn{2}{|c|}{ Floatstone } & \multicolumn{2}{|c|}{ Rudstone } & \multicolumn{2}{|c|}{$\begin{array}{l}\text { Crystalline } \\
\text { Carbonate }\end{array}$} & \multirow{2}{*}{$\begin{array}{c}\text { Total } \\
\text { abs. }\end{array}$} \\
\hline & abs. & $\%$ & abs. & $\%$ & abs. & $\%$ & abs. & $\%$ & abs. & $\%$ & abs. & $\%$ & abs. & $\%$ & abs. & $\%$ & \\
\hline \multicolumn{18}{|l|}{\begin{tabular}{|l|} 
Kpor, \%: \\
\end{tabular}} \\
\hline \begin{tabular}{|l|} 
From 0 to 5 \\
$($ Zone 1$)$
\end{tabular} & 1 & 0.4 & 2 & 0.8 & 60 & 22.6 & 25 & 9.40 & 95 & 35.7 & 10 & 3,8 & 67 & 25,2 & 6 & 2,1 & 266 \\
\hline $\begin{array}{l}\text { From } 5 \text { to } 12 \\
(\text { Zone } 2)\end{array}$ & - & - & 4 & 2.4 & 41 & 24.6 & 19 & 11.4 & 56 & 33.5 & 8 & 4,8 & 30 & 18,0 & 9 & 5,4 & 167 \\
\hline $\begin{array}{l}\text { From } 12 \text { to } 20 \\
\text { (Zone 3) }\end{array}$ & 2 & 1.4 & 1 & 0.8 & 17 & 12.9 & 38 & 28.8 & 34 & 27.3 & 6 & 4,5 & 18 & 13,6 & 16 & 12,1 & 132 \\
\hline \begin{tabular}{|l|} 
Over 20 \\
(Zone 4)
\end{tabular} & 1 & 1.4 & 3 & 4.1 & 15 & 20.3 & 7 & 9.5 & 16 & 23.0 & 1 & 1,4 & 8 & 10,8 & 23 & 31,1 & 74 \\
\hline $\begin{array}{l}\text { Average value } \\
\text { for all zones }\end{array}$ & 4 & 0.6 & 10 & 1.6 & 133 & 20.8 & 89 & 13.9 & 201 & 31.5 & 25 & 3,9 & 123 & 19,2 & 54 & 8,5 & 639 \\
\hline \multicolumn{18}{|l|}{ Kperm, mD: } \\
\hline \begin{tabular}{|l|}
$0.01-1$ \\
(Zone 1)
\end{tabular} & - & - & 5 & 1.4 & 86 & 24.7 & 41 & 11.8 & 110 & 31.6 & 15 & 4,3 & 77 & 22,1 & 14 & 4,0 & 348 \\
\hline $\begin{array}{l}\text { From } 1 \text { to } 10 \\
\text { (Zone 2) }\end{array}$ & 2 & 1.6 & 3 & 2.3 & 22 & 17.1 & 20 & 15.5 & 38 & 29.5 & 6 & 4,7 & 27 & 20,9 & 11 & 8,5 & 129 \\
\hline \begin{tabular}{|l|} 
From 10 to \\
100 \\
(Zone 3) \\
\end{tabular} & - & - & 2 & 1.7 & 20 & 17.4 & 24 & 20.9 & 32 & 27.8 & 2 & 1,7 & 17 & 14,8 & 18 & 15,7 & 115 \\
\hline \begin{tabular}{|l|} 
Over 100 \\
(Zone 4)
\end{tabular} & 2 & 4.3 & - & - & 5 & 10.6 & 4 & 8.5 & 21 & 44.7 & 2 & 4,3 & 2 & 4,3 & 11 & 23,3 & 47 \\
\hline $\begin{array}{l}\text { Average value } \\
\text { for all zones }\end{array}$ & 4 & 0.6 & 10 & 1.6 & 133 & 20.8 & 89 & 13.9 & 201 & 31.5 & 25 & 3,9 & 123 & 19,2 & 54 & 8,5 & 639 \\
\hline
\end{tabular}


In order to determine how the lithological features change the flow properties of 5,000 core samples, we plotted a graph of Pearson's cumulative correlation against the absolute gas permeability ratio for all the samples (Fig. 2, c) and for the samples with the identified Dunham texture (Fig. 2, d). The number of zones in the graphs is drawn by analogy with the data given in Figure $2(a, b)$, which results from the influence similarity of the lithogenesis type on the porosity and permeability properties of the reservoirs.

For the absolute gas permeability distribution over the entire range of properties, Boundstone contributes the most (Table 3), which indicates their uniform distribution and strong influence over the entire property range. Mudstone, Wackestone and Floatstone have the least impacts.

A pronounced anisotropy of the flow properties is a distinctive feature of the field reservoirs. The permeability of the full-size samples depending on direction varies by $1-2$ and sometimes 3 orders of magnitude. In certain cases, the difference reaches 4 orders of magnitude. A comparison of the gas permeability depending on direction is shown in Fig. 3. There are four zones outlined in the graph. It can be seen that different degrees of azimuthal heterogeneity are determined depending on a zone. In Zone 1 and Zone 2, azimuthal anisotropy is not as significant as in Zone 3 and Zone 4.

The gas permeability measured in the direction parallel to bedding varies within the range of (0.01$15578.66) 10^{-3} \mu \mathrm{m}^{2}$ with an average value of $430.20 \cdot 10^{-3} \mu \mathrm{m}^{2}$, and perpendicular to the bedding within the range of $(<0.01-11467.87) 10^{-3} \mu \mathrm{m}^{2}$ with an average value of $222.37 \cdot 10^{-3} \mu \mathrm{m}^{2}$. The anisotropy ratio (a value expressed by the square root of the quotient of the formation permeability in the horizontal direction by its vertical permeability) was 1.58 . It should be noted that

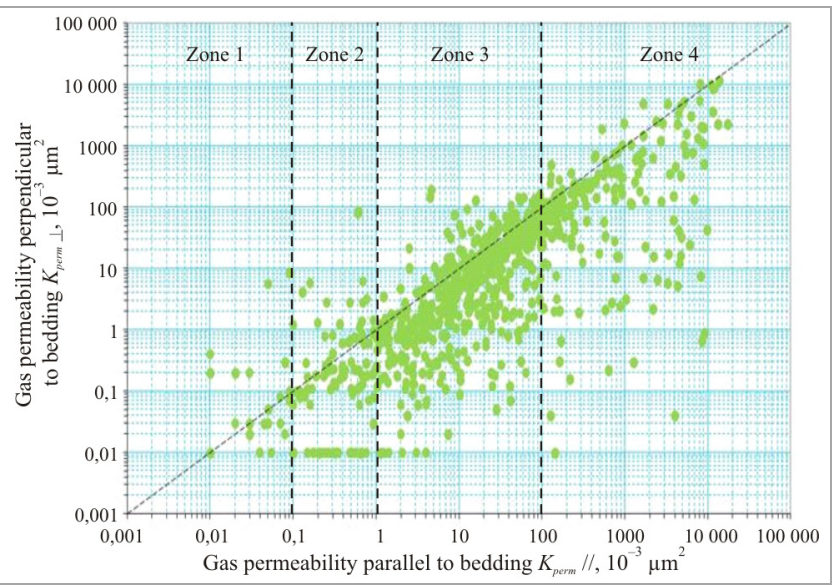

Fig. 3. Comparison of the gas permeability of the carbonate rocks of the Permo-Carboniferous deposit parallel and perpendicular to bedding the rocks of the Usinskoye field exhibit vertical anisotropy, as well as lateral anisotropy. The ratio of lateral anisotropy is 1.34 .

\section{Conclusions}

Based on the lithological, petrographic and petrophysical research findings, we studied how various petrotypes/lithotypes change the porosity and permeability of the reservoirs for the Usinskoye field. The authors identified four types of reservoirs and eight different types of lithogenesis, and assessed the geological and physical parameters for each of them. Based on the cumulative correlation plots, we identified four zones of heterogeneity that are subject to the influence of the core samples' properties of various lithogenesis types. The influence of the structural heterogeneity and lithogenesis type on changes in the porosity and permeability over their entire range was assessed. This is the first time that the full-size core studies with account for the identified zones have been studied, which made it possible to assess the degree of azimuthal anisotropy for each of the zones. The experiments proved that the rocks of the PermoCarboniferous deposit of the Usinskoye field have extremely heterogeneous permeability properties that vary much. Thus, it is necessary to differentiate the core-to-core petrophysical correlations depending on a fabric of its void space and lithology of rocks.

\section{References}

1. Gurbatova I.P., Melekhin S.V., Iur'ev A.V. Osobennosti izucheniia petrofizicheskikh i uprugikh svoistv kerna $\mathrm{v}$ slozhnopostroennykh kollektorakh nefti i gaza pri modelirovanii termobaricheskikh plastovykh uslovii [Research features of petrophysical and elastic core characteristics in oil and gas compound reservoirs under thermobaric in-place conditions simulation]. Geologiia, geofizika $i$ razrabotka neftianykh $i$ gazovykh mestorozhdenii, 2010, no. 5, pp. 67-72.

2. Kostin N.G., Gubaidullin M.G. Vliianie razmerov issleduemykh obraztsov kerna na velichinu koeffitsienta poristosti karbonatnykh i terrigennykh kollektorov [The influence of the sizes of the studied core samples on the value of the porosity coefficient of carbonate and terrigenous reservoirs]. Geologicheskie opasnosti. Materialy $\mathrm{KhV}$ Vserossiiskoi konferentsii s mezhdunarodnym uchastiem. Arkhangel'sk, 2009, pp. 248-250.

3. Petersil'e V.I., Rabits E.G., Belov Iu.Ia. Metody i apparatura dlia izucheniia fil'tratsionno-emkostnykh svoistv porod-kollektorov na obraztsakh bol'shogo razmera [Methods and 
apparatus for studying the reservoir properties of reservoir rocks on large samples]. Moscow, Nedra, 1980, $53 \mathrm{p}$.

4. Aleksin G.A., Kleshchev A.A., Rossikhin Iu.A. Perspektivy poiskov nefti i gaza na severe TimanoPechorskoi provintsii [Prospects for oil and gas exploration in the north of the Timan-Pechora province]. Moscow, VNIIOENG, 1982, $44 \mathrm{p}$.

5. Dougias R., Rasoul A. Reconsidering Klinkenbergs permeability data. SCA. Norway, 2018, 1 p.

6. Arabjamaloei R., Daniels D., Ebeltoft E. Validation of permeability and relative permeability data using mercury injection capillary pressure data. SCA. Norway, 2018, 2 p.

7. Shaw D., Mastaghimi P., Hussein F., Armstrong R. Insights, trends and challenges associated with measuring goal relative permeability. SCA. Norway, 2018, 10 p.

8. Pruno S., Rodvent H.E., Scjaeveland O. Measurement of spontaneous imbibition capillary pressure saturation and resistivity index by counter technique at net reservoir stress and elevated temperature. SCA. Norway, 2018, $2 \mathrm{p}$.

9. Faurissoux P., Lutui-Tefuka M., Caubit C., Lalanne B., Nicot B. A fast method for trapped gas determination. SCA. Norway, 2018, 2 p.

10. Gurbatova I.P., Mikhailov N.N. Izuchenie anizotropii slozhnopostroennykh karbonatnykh kollektorov laboratornymi metodami [Laboratory study of anisotropy of complex carbonate reservoirs]. Aktual'naia problema razvitiia neftegazovogo kompleksa Rossii. Sbornik tezisov dokladov VIII Vserossiiskoi nauchno-tekhnicheskoi konferentsii. Moscow, 2010, part 1, pp. 94-95.

11. Gurbatova I.P., Kuz'min V.A., Mikhailov N.N. Vliianie struktury porovogo prostranstva na masshtabnyi effekt pri izuchenii fil'tratsionnoemkostnykh svoistv slozhnopostroennykh karbonatnykh kollektorov [Influence of pore space structure on the scale effect in studying permeability storage capacity of complicatedly built carbonate reservoirs]. Geologiia nefti $i$ gaza, 2011, no. 2, pp. 74-82.

12. Gurbatova I.P., Glushkov D.V., Rekhachev P.N., Melekhin S.V., Popov N.A. Osobennosti izucheniia karbonatnykh porod-kollektorov laboratornymi metodami, filial OOO "LUKOILInzhiniring" "PermNIPIneft"” $\mathrm{v}$ gorode Permi [Features of the study of carbonate reservoir rocks by laboratory methods, PermNIPIneft branch of PermNIPIneft LLC in Perm]. Perm: Aster Didzhital, 2017, 264 p.

13. Mikhailov N.N., Gurbatova I.P. Masshtabnyi effekt pri laboratornom opredelenii fil'tratsionno- emkostnykh svoistv slozhnopostroennykh karbonatnykh kollektorov [Scale Effect at Laboratory Determination of Permeability and Porosity Properties of Complex Structured Carbonate Reservoirs]. Tekhnologii nefti i gaza, 2011, vol. 75, no. 4 , pp. 32-35.

14. Putilov I.S., Rekhachev P.N., Gurbatova I.P., Barkovskii N.N., Iakimov O.I., Moroziuk O.A. Epokha polnorazmernogo kerna pri laboratornykh issledovaniiakh tekhnologii povysheniia nefteotdachi plastov [Full-size core epoch at laboratory research of eor technologies]. Vestnik Permskogo natsional'nogo issledovatel'skogo politekhnicheskogo universiteta. Geologiia. Neftegazovoe $i$ gornoe delo, 2016, vol. 15, no. 19, pp. 155-164. DOI: $10.15593 / 2224-9923 / 2016.19 .6$

15. Sukhodanova S.S. Sozdanie 3D-modeli zalezhi s karbonatnymi treshchinovatymi kollektorami na osnove kompleksirovaniia gidrodinamicheskikh, geofizicheskikh, seismicheskikh i promyslovykh dannykh (na primere nizhnepermskikh otlozhenii Varandeiskogo mestorozhdeniia) [Creation of a 3D-model of a reservoir with carbonate fractured reservoirs based on a combination of hydrodynamic, geophysical, seismic and field data (for example, the Lower Permian deposits of the Varandey field)]. Ph.D. thesis: 25.00.17. Moscow, 2016, $157 \mathrm{p}$.

16. Advances in core evaluation. Accuracy and precision in reserves estimation. Reviewed Proceedings of the First Society of Core Analysts European Core Analysis Symposium. London, $1990,567 \mathrm{p}$.

17. Sbornik smetnykh norm na geologorazvedochnye raboty. Vypusk 7 . Laboratornye issledovaniia poleznykh iskopaemykh $\mathrm{i}$ gornykh porod [Collection of estimated standards for exploration. Iss. 7. Laboratory studies of minerals and rocks]. Moscow: VIEMS, 1993, $70 \mathrm{p}$.

18. GOST 26450.1-85. Porody gornye. Metod opredeleniia koeffitsienta otkrytoi poristosti zhidkostenasyshcheniem [GOST 26450.1-85. The rocks are mountain. Method for determining the coefficient of open porosity by liquid saturation]. Moscow: Izdatel'stvo standartov, $1985,7 \mathrm{p}$.

19. MR-ISM-03-OLFI-046-2013. Gornye porody. Opredelenie koeffitsienta otkrytoi poristosti gazovoliumetricheskim metodom [MR-ISM-03-OLFI046-2013. Rocks. Determination of the coefficient of open porosity by the gas-volumetric method]. Perm, Filial OOO «LUKOIL-Inzhiniring» «PermNIPIneft'» v Permi, 2013, $22 \mathrm{p}$.

20. Gubaidullin M.G., Belozerov I.P., Iur'ev A.V. Eksperimental'nye issledovaniia otnositel'nykh fazovykh pronitsaemostei i koeffitsienta vytesneniia 
nefti vodoi $\mathrm{v}$ slozhnopostroennykh kollektorakh [Experimental study of relative phase permeability and factors of oil replacement by water in complicatedly-composed reservoirs]. Geologiia, geofizika $i$ razrabotka neftianykh $i$ gazovykh mestorozhdenii, 2017, no. 2, pp. 49-52.

21. Dmitriev M.N., Kadet V.V., Kravchenko M.N., Rossokhin S.G. Dvukhfaznaia fil'tratsiia v transversal'no-izotropnoi poristoi srede. Teoriia i eksperiment [Two-phase filtration in a transversely isotropic porous medium. Theory and experiment]. Izvestiia Rossiiskoi akademii nauk, 2004, no. 4, pp. 92-97.

22. Dmitriev N.M., Kuz'michev A.N., Mikhailov N.N., Maksimov V.M. Eksperimental'noe izuchenie fil'tratsionnykh svoistv anizotropnykh kollektorov uglevodorodnogo syr'ia [Experimental study of filtration properties of hydrocarbons anisotropic fields]. Burenie i neft', 2015, no. 11, pp. 6-9.

23. Zheltov Iu.V., Kudinov V.I., Malofeev G.E. Razrabotka slozhnopostroennykh mestorozhdenii viazkoi nefti $\mathrm{v}$ karbonatnykh kollektorakh [Development of complex viscous oil fields in carbonate reservoirs]. Moscow: Neft' i gaz, 1997, $387 \mathrm{p}$.

24. Zainutdinov R.S. Sovershenstvovanie metoda opredeleniia ostatochnoi neftenasyshchennosti plastov po kernu dlia otsenki koeffitsientov vytesneniia nefti vodoi [Improving the method for determining the residual oil saturation of the strata from the core to assess the coefficients of oil displacement by water]. Ph.D. thesis: 05.15.06. Ufa, 1998, $162 \mathrm{p}$.

25. Zubkov M.Iu., Mikulina O.I., Pushin A.V. Rezul'taty issledovanii otnositel'nykh fazovykh pronitsaemostei raznovozrastnykh produktivnykh otlozhenii Krasnoleninskogo mestorozhdeniia [The results of studies of the relative phase permeabilities of different age productive deposits of the Krasnoleninsky field]. Vestnik nedropol'zovaniia Khanty-Mansiiskogo avtonomnogo okruga, 2012, no. 25, pp. 42-52.

26. Masket M. Techenie odnorodnykh zhidkostei $\mathrm{v}$ poristoi srede [The flow of homogeneous liquids in a porous medium]. Moscow: NITs Reguliarnaia i khaoticheskaia dinamika, 2004, 629 p.

27. Mikhailov N.N., Dzhemesiuk A.V., Kol'chitskaia T.N., Semenova N.A. Izuchenie ostatochnogo neftenasyshcheniia razrabatyvaemykh plastov [The study of residual oil saturation of the developed formations]. Moscow: VNIIOENG, 1990, $59 \mathrm{p}$.

28. Tul'bovich B.I. Metody izucheniia porodkollektorov nefti i gaza [Methods for the study of reservoir rocks of oil and gas]. Moscow: Nedra, 1979, $301 \mathrm{p}$.
29. Khairedinov N.Sh., Gubaidullin A.A., Iudintsev E.A., Blinov S.A. Nekotorye rezul'taty otsenki vliianiia sposobov ekstraktsii neftenasyshchennykh karbonatnykh porod na ikh kollektorskie svoistva [Some results of evaluating the influence of methods for the extraction of oil-saturated carbonate rocks on their reservoir properties]. Trudy TatNIPIneft'. Bugulma, 1987, no. 60, pp. 103-109.

30. Shvanov V.N., Frolov V.T., Sergeeva E.I. Sistematika i klassifikatsiia osadochnykh porod i ikh analogov [Systematics and classification of sedimentary rocks and their analogues]. Saint Petersburg: Nedra, 1998, $521 \mathrm{p}$.

31. Herrera R.G., Fernando S.V., Hernandez F.P. On the Petrophysics of Carbonate Reservoirs Through Whole Cole Analysis. Society of Petroleum Engineers, International Petroleum Conference and Exhibition of Mexico, 10-13 October, Veracruz, Mexico, 1994.

32. Pore Geometry of Carbonate Rocksand Capillary Pressure Curves / R.L. Jodry, G.V. Cinilingarian, S.J. Mazzuiloand, H.H. Rieke. Carbonate Reservoir Characterization: A Geologic-Engineering Analysis, part I, Elsevier, Amsterdam, 1992, $670 \mathrm{p}$.

33. Samaniego V.F., Chilingarian G.V., Mazzullo S.J., Rieke H.H. Fluid Flow Through Carbonate Rock Sytems. Carbonate Reservoir Characterization: A Geologic-Engineering Analysis, part I, Elsevier, New York, 1992, pp. 439-503.

34. Skopec R.A. Proper Coring and Wellsite Core Handling Procedures: The First Step Toward Rliable Core Analysis. J. Pet. Tech. April, 1994, vol. 33, no. $3,280 \mathrm{p}$.

35. Chilingarin G.V., Mazzullo S.J., Rieke H.H. Carbonate reservoir characterization: a geologic engineering analysis, part 2, Elsevier, 1996, $993 \mathrm{p}$.

36. Denney D. Whole Core vs. Plugs: Integrating Log and Core Data to Decrease Uncertainty in Petrophysical Interpretation and Oil-In-Place Calculations. Journal of Petroleum Technology, 2011, vol. 63, SPE, no. 0811-0058-JPT, pp. 58-60.

37. Honarpour M.M., Mahmood S.M. RelativePermeability Measurements: An Overview. Journal of Petroleum Technology, 1998, vol. 40, SPE, no. 18565-PA, pp. 15-19.

38. McPhee C.A., Arthur K.G. Relative Permeability Measurements: An Inter-Laboratory Comparison. European Petroleum Conference, 25-27 October, London, United Kingdom, 1994, pp. 199-211.

39. Dement'ev L.F. Statisticheskie metody obrabotki i analiza promyslovo-geologicheskikh 
dannykh [Statistical methods for processing and analyzing field geological data]. Moscow: Nedra, 1966, $206 \mathrm{p}$.

40. Mirzadzhanzade A.Kh., Stepanova G.S. Matematicheskaia teoriia eksperimenta $\mathrm{v}$ dobyche nefti i gaza [The mathematical theory of an experiment in oil and gas production]. Moscow: Nedra, 1977, $228 \mathrm{p}$.

41. Chini R.F. Statisticheskie metody v geologii [Statistical methods in geology]. Moscow: Mir, 1986, 189 p.

42. Sharapov I.P. Primenenie matematicheskoi statistiki v geologii [The use of mathematical statistics in geology]. Moscow: Nedra, 1965, $260 \mathrm{p}$.

43. Johnson N.L., Leone F.C. Statistics and experimental design. New York - London - Sydney Toronto, 1977, $606 \mathrm{p}$.

44. Montgomery D.C., Peck E.A. Introduction to liner regression analysis. New York: John Wiley \& Sons, 1982, $504 \mathrm{p}$.

45. Watson G.S. Statistic on spheres. New York: John Wiley and Sons, Inc., 1983, 238 p.

46. Yarus J.M. Stochastic modeling and geostatistics. AAPG. Tulsa, Oklahoma, 1994, 231 p.

\section{Библиографический список}

1. Гурбатова И.П., Мелехин С.В., Юрьев А.В. Особенности изучения петрофизических и упругих свойств керна в сложнопостроенных коллекторах нефти и газа при моделировании термобарических пластовых условий // Геология, геофизика и разработка нефтяных и газовых месторождений. 2010. - № 5. - C. 67-72.

2. Костин Н.Г., Губайдуллин М.Г. Влияние размеров исследуемых образцов керна на величину коэффициента пористости карбонатных и терригенных коллекторов // Геологические опасности: материалы XV Bсерос. конф. с междунар. участием. - Архангельск, 2009. - С. 248-250.

3. Петерсилье В.И., Рабиц Э.Г., Белов Ю.Я. Методы и аппаратура для изучения фильтрационноемкостных свойств пород-коллекторов на образцах большого размера. - М.: Недра, 1980. $53 \mathrm{c}$.

4. Алексин Г.А., Клещев А.А., Россихин Ю.А. Перспективы поисков нефти и газа на севере Тимано-Печорской провинции. - М.: ВНИИОЭНГ, 1982. $-44 \mathrm{c}$.

5. Dougias R., Rasoul A. Reconsidering Klinkenbergs permeability data. - SCA. Norway, 2018. $-1 \mathrm{p}$.

6. Arabjamaloei R., Daniels D., Ebeltoft E. Validation of permeability and relative permeability data using mercury injection capillary pressure data. SCA. Norway, 2018. -2 p.
7. Shaw D., Mastaghimi P., Hussein F., Armstrong R. Insights, trends and challenges associated with measuring goal relative permeability. - SCA. Norway, 2018. $-10 \mathrm{p}$.

8. Pruno S., Rodvent H.E., Scjaeveland O. Measurement of spontaneous imbibition capillary pressure saturation and resistivity index by counter technique at net reservoir stress and elevated temperature. - SCA. Norway, 2018. $-2 \mathrm{p}$.

9. A fast method for trapped gas determination / P. Faurissoux, M. Lutui-Tefuka, C. Caubit, B. Lalanne, B. Nicot. - SCA. Norway, 2018. -2 p.

10. Гурбатова И.П., Михайлов Н.Н. Изучение анизотропии сложнопостроенных карбонатных коллекторов лабораторными методами // Актуальная проблема развития нефтегазового комплекса России: сб. тез. докл. VIII Всерос. науч.-техн. конф. - М., 2010. - Ч. 1. - С. 94-95.

11. Гурбатова И.П., Кузьмин В.А., Михайлов Н.Н. Влияние структуры порового пространства на масштабный эффект при изучении фильтрационноемкостных свойств сложнопостроенных карбонатных коллекторов // Геология нефти и газа. 2011. - № 2. - C. 74-82.

12. Особенности изучения карбонатных породколлекторов лабораторными методами / Фил. ООО «ЛУКОЙЛ-инжиниринг» «ПермНИПИнефть» в г. Перми; И.П. Гурбатова, Д.В. Глушков, П.Н. Рехачев, С.В. Мелехин, Н.А. Попов. - Пермь: Астер Диджитал, 2017. - 264 с.

13. Михайлов Н.Н., Гурбатова И.П. Масштабный эффект при лабораторном определении фильтрационно-емкостных свойств сложнопостроенных карбонатных коллекторов // Технологии нефти и газа. - 2011. - Т. 75, № 4. C. 32-35.

14. Эпоха полноразмерного керна при лабораторных исследованиях технологий повышения нефтеотдачи пластов / И.С. Путилов, П.Н. Рехачев, И.П. Гурбатова, Н.Н. Барковский, О.И. Якимов, О.А. Морозюк // Вестник Пермского национального исследовательского политехнического университета. Геология. Нефтегазовое и горное дело. - 2016. - Т. 15, № 19. - С. 155-164. DOI: $10.15593 / 2224-9923 / 2016.19 .6$

15. Суходанова С.C. Создание 3D-модели залежи с карбонатными трещиноватыми коллекторами на основе комплексирования гидродинамических, геофизических, сейсмических и промысловых данных (на примере нижнепермских отложений Варандейского месторождения): дис. ... канд. техн. наук: 25.00.17. M., 2016. -157 c.

16. Advances in core evaluation. Accuracy and precision in reserves estimation // Reviewed 
Proceedings of the First Society of Core Analysts European Core Analysis Symposium. - London, 1990. -567 p.

17. Сборник сметных норм на геологоразведочные работы. - Вып. 7: Лабораторные исследования полезных ископаемых и горных пород. - М.: ВИЭМС, 1993. - 70 с.

18. ГОСТ 26450.1-85. Породы горные. Метод определения коэффициента открытой пористости жидкостенасыщением. - М.: Изд-во стандартов, 1985. - 7 c.

19. МР-ИСМ-03-ОЛФИ-046-2013. Горные породы. Определение коэффициента открытой пористости газоволюметрическим методом. Пермь: Филиал ООО «ЛУКОЙЛ-Инжиниринг» «ПермНИПИнефть» в г. Перми, 2013. $22 \mathrm{c}$.

20. Губайдуллин М.Г., Белозеров И.П., Юрьев А.В. Экспериментальные исследования относительных фазовых проницаемостей и коэффициента вытеснения нефти водой в сложнопостроенных коллекторах // Геология, геофизика и разработка нефтяных и газовых месторождений. - 2017. № 2. - С. 49-52.

21. Двухфазная фильтрация в трансверсальноизотропной пористой среде. Теория и эксперимент / М.Н.Дмитриев, В.В. Кадет, М.Н. Кравченко, С.Г. Россохин // Известия РАН. - 2004. - № 4. C. $92-97$.

22. Экспериментальное изучение фильтрационных свойств анизотропных коллекторов углеводородного сырья / Н.М. Дмитриев, А.Н. Кузьмичев, Н.Н. Михайлов, В.М. Максимов // Бурение и нефть. - 2015. - № 11. - С. 6-9.

23. Желтов Ю.В., Кудинов В.И., Малофеев Г.Е. Разработка сложнопостроенных месторождений вязкой нефти в карбонатных коллекторах. М.: Нефть и газ, 1997. - 387 с.

24. Зайнутдинов P. С. Совершенствование метода определения остаточной нефтенасыщенности пластов по керну для оценки коэффициентов вытеснения нефти водой: дис. ... канд. техн. наук: 05.15.06. - Уфа, 1998. - 162 с.

25. Зубков М.Ю., Микулина О.И., Пушин А.В. Результаты исследований относительных фазовых проницаемостей разновозрастных продуктивных отложений Красноленинского месторождения // Вестник недропользования Ханты-Мансийского автономного округа. - 2012. - № 25. C. $42-52$.

26. Маскет М. Течение однородных жидкостей в пористой среде. - М.: Издательство НИЦ Регулярная и хаотическая динамика, 2004. - 629 с.

27. Изучение остаточного нефтенасыщения разрабатываемых пластов / Н.Н. Михайлов,
А.В. Джемесюк, Т.Н. Кольчицкая, Н.А. Семенова. М.: Изд-во ВНИИОЭНГ, 1990. - 59 с.

28. Тульбович Б.И. Методы изучения породколлекторов нефти и газа. - М.: Недра, 1979. $301 \mathrm{c.}$

29. Некоторые результаты оценки влияния способов экстракции нефтенасыщенных карбонатных пород на их коллекторские свойства / Н.Ш. Хайрединов, А.А. Губайдуллин, Е.А. Юдинцев, С.А. Блинов // Труды ТатНИПИнефть. Бугульма, 1987. - № 60. - С. 103-109.

30. Шванов В.Н., Фролов В.Т., Сергеева Э.И. Систематика и классификация осадочных пород и их аналогов. - СПб.: Недра, 1998. $521 \mathrm{c}$.

31. Herrera R.G., Fernando S.V., Hernandez F.P. On the petrophysics of carbonate reservoirs through whole cole analysis // Society of Petroleum Engineers, International Petroleum Conference and Exhibition of Mexico, 10-13 October. - Veracruz, Mexico, 1994.

32. Pore geometry of carbonate rocksand capillary pressure curves / R.L. Jodry, G.V. Cinilingarian, S.J. Mazzuiloand, H.H. Rieke // Carbonate Reservoir Characterization: A Geologic-Engineering Analysis. - Part I. - Elsevier, Amsterdam, 1992. $670 \mathrm{p}$.

33. Fluid flow through carbonate rock sytems / V.F. Samaniego, G.V. Chilingarian, S.J. Mazzullo, H.H. Rieke // Carbonate Reservoir Characterization: A Geologic-Engineering Analysis. - Part I. - Elsevier, NewYork, 1992. - P. 439-503.

34. Skopec R.A. Proper coring and wellsite core handling procedures: the first step toward rliable core analysis // J. Pet. Tech. April. - 1994. Vol. 33, № 3. - 280 p.

35. Chilingarin G.V., Mazzullo S.J., Rieke H.H. Carbonate reservoir characterization: a geologic engineerin analysis. - Part 2. - Elsevier, 1996. 993 p.

36. Denney D. Whole Core vs. plugs: integrating $\log$ and core data to decrease uncertainty in petrophysical interpretation and oil-in-place calculations // Journal of Petroleum Technology. 2011. - Vol. 63. - SPE, № 0811-0058-JPT. P. 58-60.

37. Honarpour M.M., Mahmood S.M. Relativepermeability measurements: an overview // Journal of petroleum technology. - 1998. - Vol. 40. - SPE, № 18565-PA. - P. 15-19.

38. McPhee C.A., Arthur K.G. Relative Permeability Measurements: An Inter-Laboratory Comparison // European Petroleum Conference, 25-27 October. - London, United Kingdom, 1994. P. 199-211. 
39. Дементьев Л.Ф. Статистические методы обработки и анализа промыслово-геологических данных. - М.: Недра, 1966. - 206 с.

40. Мирзаджанзаде А.Х., Степанова Г.С. Математическая теория эксперимента в добыче нефти и газа. - М.: Недра, 1977. - 228 с.

41. Чини Р.Ф. Статистические методы в геологии. - М.: Мир, 1986. - 189 с.

42. Шарапов И.П. Применение математической статистики в геологии. - М.: Недра, 1965. $260 \mathrm{c}$.
43. Johnson N.L., Leone F.C. Statistics and experimental design. - New York - London - Sydney Toronto, 1977. $-606 \mathrm{p}$.

44. Montgomery D.C., Peck E.A. Introduction to liner regression analysis. - New York: John Wiley \& Sons, 1982. $-504 \mathrm{p}$.

45. Watson G.S. Statistic on spheres. - New York: John Wiley and Sons, Inc., 1983. - 238 p.

46. Yarus J.M. Stochastic modeling and geostatistics // AAPG. - Tulsa, Oklahoma, 1994. $231 \mathrm{p}$.

Please cite this article in English as:

Popov N.A., Putilov I.S., Guliaeva A.A., Vinokurova E.E., Fairuzova Iu.V. Influence of the lithogenesis type of rocks on porosity and permeability properties (the case of the Permo-carboniferous deposit of the Usinskoye field). Perm Journal of Petroleum and Mining Engineering, 2020, vol.20, no.2, pp.104-114. DOI: 10.15593/2224-9923/2020.2.1

Просьба ссылаться на эту статью в русскоязычных источниках следующим образом:

Влияние литогенетического типа горных пород на фильтрационно-емкостные свойства (на примере пермокабоновой залежи Усинского месторождения) / Н.А. Попов, И.С. Путилов, А.А. Гуляева, Е.Е. Винокурова, Ю.В. Файрузова // Вестник Пермского национального исследовательского политехнического университета. Геология. Нефтегазовое и горное дело. - 2020. - Т.20, №2. - С.104-114. DOI: 10.15593/2224-9923/2020.2.1 